\title{
USE OF BIO-DEGRADABLE STENTS FOR THE TREATMENT OF REFRACTORY BENIGN GASTROINTESTINAL STENOSES
}

\begin{abstract}
Stanislav Rejchrt', Jan Burešl, Jan Brožík ${ }^{2}$, Marcela Kopáčováa ${ }^{1}$
Charles University in Prague, Faculty of Medicine and University Hospital Hradec Králové, Czech Republic: 2nd Department of Medicine ${ }^{1}$, Department of Radiology ${ }^{2}$

Summary: Bio-degradable stents are be made of different synthetic polymers (like polylactide or polyglycolide) or their co-polymers (polydioxanone). They can be used for treating benign stenoses of the small and large intestine, particularly in Crohn's disease. Endoscopic introduction of bio-degradable stents into small and large intestinal stenoses is feasible and relatively simple. Initial results are encouraging and the complication rate is low. However, there are still some difficulties that need to be overcome. The rate of early stent migration is still rather high (up to one third of patients). This might be solved by changes in the shape or rigidity of the stents as well as by further improvement in the design. Proof of long-term efficacy and safety requires further studies.
\end{abstract}

Key words: Bio-degradable stents; Crohn's disease; Double balloon endoscopy; Polydioxanone; Intestinal benign stenoses

\section{Introduction}

Self-expanding metal stents play an important role in the palliative management of malignant stenoses in the gastrointestinal tract, including the small intestine (1-9). As their placement and removal may be associated with several problems and drawbacks, use of metallic stents for treating benign stenoses of the gastrointestinal tract, and the small and large bowel in particular, should be restricted to situations in which all other treatment has failed. The uncovered metal part or flared ends of covered stents induce early mucosal hyperplastic reaction (with over- and/or in-growth) and thus shorter patency. Removal of these embedded stents afterwards can be extremely difficult. Plastic stents are associated with a higher risk of migration and lower flexibility and shorter/lower radial force (10-15). Stents made of bio-degradable materials could theoretically overcome the above-mentioned shortcomings of metallic and plastic stents as they do not require removal (16-18).

\section{Bio-degradable materials}

Bio-degradable materials are natural substances or synthetic compounds which disintegrate over time in the human body at the location of their implantation. Bio-degradable materials have been used for decades in surgery (e.g. absorbable sutures). Nowadays, they are also being tried in gastroenterology, urology, cardiology, ophthalmology, ENT and other disciplines.

Bio-degradable stents can be made of different synthetic polymers (e.g. polylactide or polyglycolide) or their co-polymers (polydioxanone or caprolactone), polyethylene glycol, hybrid polyurethanes, chitosan glycerophosphate, hydroxyapatite non-polymer substance, manganese or magnesium alloys, special corrodible iron and others (19-25). To decrease intimal reaction, bio-degradable polymers can be coated with radioactive compounds or drugs such as tacrolimus, biolimus, sirolimus, paclitaxel, aspirin or dexamethasone (19, 26-28). Radioactive and drug-eluting stents have mostly been tried in cardiology for coronary use to prevent recoil and inflammation $(23,25,29)$.

\section{Bio-degradable stents in an experimental setting}

Ginsberg et al. (30) evaluated bio-degradable stents in a porcine model of biliary stenosis. The stents were manufactured from a copolymer of 4\% D-lactide and 96\% L-lactide. The D-lactide, an enantiomer of L-lactide, was added to decrease the crystallinity of the polymer and to accelerate its absorption rate. All stents were delivered without sphincterotomy and effectively deployed endoscopically. They remained patent up to 6 months. Although there was no clinical evidence of biliary obstruction, filling defects were observed upon cholangiography. There was no bile duct integration or proliferative changes on histopathologic evaluation (30). In another study in a canine model, stents made of helical poly-L-lactic acid not only exhibited good biocompatibility but, interestingly, also provided a selfclearing effect to clear the attached bile sludge away (31).

Laukkarinen et al. $(32,33)$ tried bio-degradable polylactide stents in the biliary and pancreatic ducts in animal 
models. In their first study, a self-expanding, radio-opaque polylactide-barium sulphate bio-degradable stent was compared with a polyethylene stent in the endoscopic treatment of cystic-duct leakage after cholecystectomy in experimental pigs. In a bio-degradable group, bile output was significantly lower and the time of drain removal significantly shorter compared to the plastic stent group (32). In their second study, the same bio-degradable stents were evaluated after placement into the porcine pancreatic duct and upon follow-up. All stents disappeared within one to three months. There was no significant pathology found in the histology of the pancreas (33). The radio-opaque polylactide-barium sulphate bio-degradable stent was fully bio-compatible and non-toxic according to another study in the rat pancreas (34).

Parviainen et al. (35) performed in vitro testing of a biodegradable pancreatic stent that could be easily placed into the human pancreatic duct during surgery and the degradation of which could be easily followed up. Spiral-shaped stents were manufactured from a polylactide wire in which barium sulphate was added. The bio-degradability of the stents was studied in vitro at two different $\mathrm{pH}$ values, the first resembling that of pancreatic juice and the other that of bile. The effects of enzyme activity in the test solution and the composition of the stents (with or without the barium addition) were evaluated. Degradation of the stents occurred within 24 to 52 weeks of incubation. The alkaline milieu together with the presence of pancreatic enzyme made the stents degrade twice as fast as when either the alkaline milieu or enzyme was present alone. In the milieu resembling pancreatic juice, barium sulphate had no effect on the degradation time (35).

\section{Overall experience in gastroenterology}

In clinical use, to date, bio-degradable stents have mostly been tried for benign refractory oesophageal strictures. Fry $\&$ Fleischer (36) were the first to introduce a bio-degradable stent made of poly-L-lactide for a refractory benign oesophageal stricture. The stent disintegrated six weeks later and obstructed the oesophageal lumen. Goldin et al. (37) inserted poly-L-lactide bio-degradable stents of two different designs in five patients for benign refractory oesophageal strictures. The first three patients improved over a period of $2-3$ weeks but then suffered from a recurrence of the stricture. The last two patients received a stent built with a wider and stronger poly-L-lactide wire and were symptom-free for the next two months of follow-up.

Tanaka et al. (38) introduced stents made of polylactic acid monofilaments in two patients with oesophageal stenoses. There was no recurrence of stenoses during the next 6-month follow-up. Saito et al. (39) achieved similar results in another two patients. Bychkova et al. (40) reported on their use of a bio-degradable stent made of polydioxanone in a 4-year-old child with refractory caustic oesophageal stenosis. The stent fully disintegrated 18 weeks after implantation. Because of the recurrence of stricture, a second bio-degrada- ble stent was introduced 13 months later with a satisfactory effect for the next 18-month period of follow-up. Dhar et al. (41) presented their initial experience with a polydioxanone bio-degradable stent in four patients with benign refractory oesophageal strictures. Stent disintegration occurred in 10-12 weeks. At 3 months, the patients had no dysphagia and no additional treatment was needed. Stivaros et al. (42) reported their use of bio-degradable stents in two patients with benign and malignant oesophageal stenoses. In the first case of peptic stricture of the distal oesophagus, early migration of the stent occurred (six hours after the placement). Surprisingly, the peptic stricture appeared to be well dilated and the patient was symptom-free for the next four months. The authors stated that a migrated bio-degradable stent can be left in the stomach as it will be dissolved in hydrochloric acid, which accelerates hydrolysis. The second patient suffered from dysphagia to solids because of carcinoma of the gastro-oesophageal junction. Two bio-degradable stents had to be introduced to overcome the stenosis. The stent remained patent in subsequent follow-up. The patient died from cancer three months following stent placement (42).

Recently, Repici et al. (43) reported on their results with a polydioxanone bio-degradable stent in 12 patients with benign refractory oesophageal strictures. Stents were successfully placed in all patients, no early complications occurred. At 3 months, stents were endoscopically visible in place, but partially fragmented in $3 / 6$ patients. Stent migration was observed in two patients $(17 \%)$. One of these patients was treated using a second bio-degradable stent and was afterwards free of dysphagia. The other patient did not require any further treatment because of resolution of the stricture and absence of symptoms (43).

Parviainen et al. (35) tried a polylactide bio-degradable stent in two pilot patients for the pacreatico-jejunal anastomosis. Neither of these two patients developed any postoperative complications. These bio-degradable stents degraded faster in pancreatic than in biliary milieu (35). Petrtyl et al. (44) successfully introduced bio-degradable stents percutaneously into intrahepatic biliary strictures in two patients. Janik et al. tried bio-degradable polydioxanone stents in three patients with refractory benign strictures after radiotherapy and resection of carcinoma of the rectosigmoideum. Stent degradation occurred in all three subjects 4-5 months following implantation, and long-term anastomotic patency was demonstrated in all patients (45).

To the best of our knowledge we were the first to report on the use of bio-degradable stents in the small bowel (46).

\section{Our own existing experience}

\section{Bio-degradable stents}

Bio-degradable stents made of polydioxanone (SX-ELLA BD bio-degradable stent, ELLA-CS, Hradec Kralove, Czech Republic) were used in all patients (see Figure 1). These stents provide an extended period of dilation compared to 
conventional methods. Stent integrity and radial force were maintained for 6-8 weeks after implantation. Stent degradation and fragmentation occurs 11-12 weeks after its insertion, with the speed of degradation being $\mathrm{pH}$-dependent (faster in lower $\mathrm{pH}$ ). The dual flared-end stent design reduces the risk of migration (47).

We used different sizes of stents for each patient according to the size of the stenosis and introducer system with an

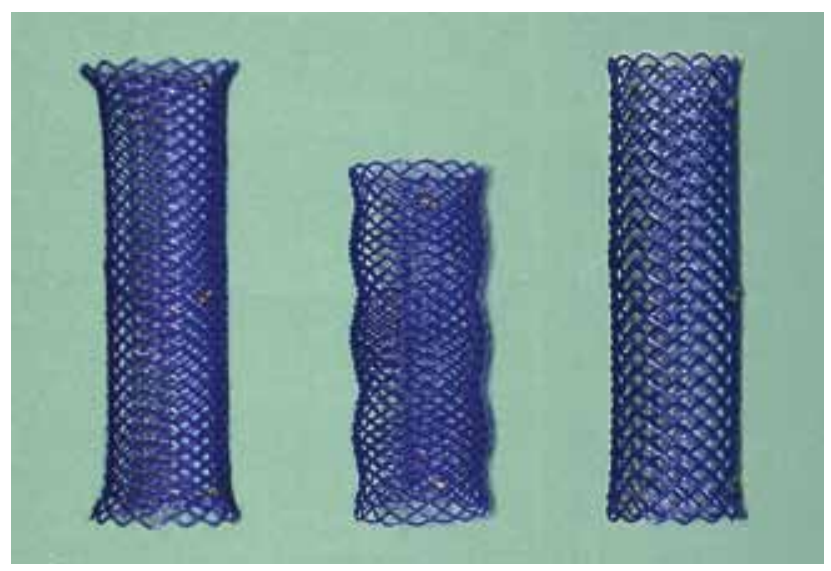

Fig. 1: A bio-degradable stent woven from polydioxanone filament, three different designs

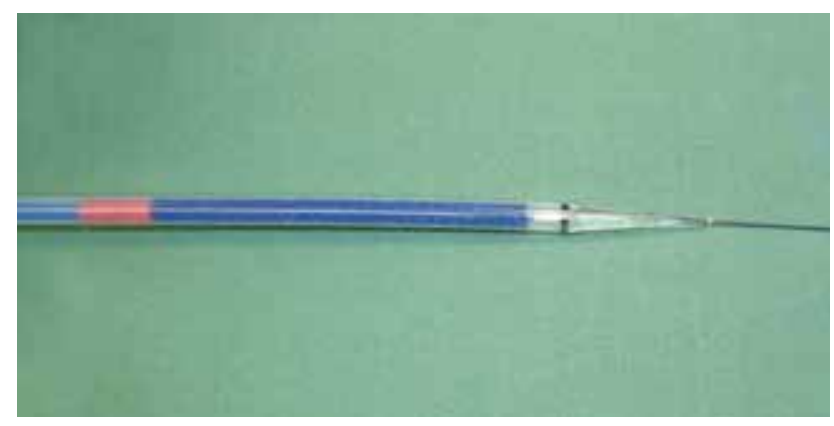

Fig. 2: The introducer system prepared for deployment: compressed stent in an introducer sheath. The introducer tip is formed by an inflated angioplasty balloon (arrow)

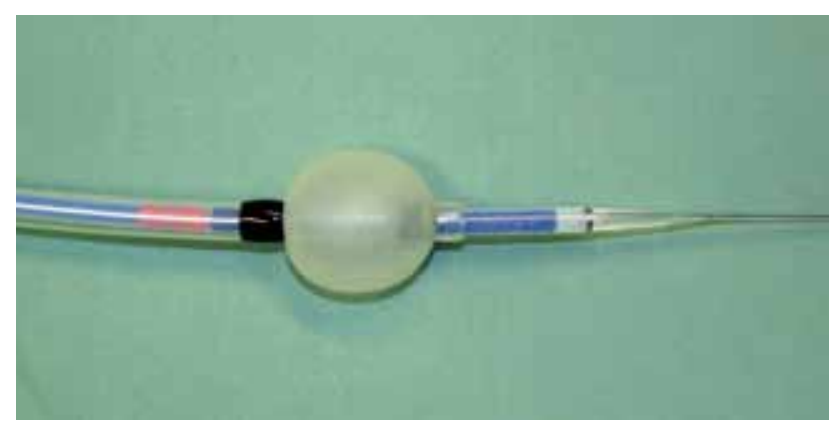

Fig. 3: Introducer system protruding from the balloon overtube outer diameter of 18-25 mm and a length of 40 to $80 \mathrm{~mm}$. Stents are fitted with radio-opaque markers at each end and a mid-point to enable precise stent positioning under fluoroscopy control. The standard delivery system for oesophageal implantation, which may be used in cases of distal (rectal) stenoses, consists of a shaft with a detachable olive. For proximal stenoses, a special introduction system for stent insertion through the balloon overtube was developed. The stent must be loaded just before implantation (see Figures 2 and 3). For details, see Ref. 48.

\section{Patients}

Eleven patients with stenosing small and/or large intestinal Crohn's disease entered the initial study (48). Significant stenoses were found in the small intestine (1 case), large bowel ( 2 cases) and ileo-colonic anastomoses after previous surgery (see Figure 4) (8 cases). In addition to bio-degradable stent insertion, the patients also received pharmacotherapy (including anti-TNF treatment, azathioprine and enteral nutrition by polymeric formula).

\section{Endoscopy}

A double balloon enteroscopy or colonoscopy system (Fujinon, Saitama City, Japan) was used in all cases. With the patient under conscious sedation (i.v. midazolam and pentazocine), all procedures were accomplished per anum in one of two ways: a therapeutic enteroscope EN 450T5 (working channel $2.8 \mathrm{~mm}$; outer diameter $9.4 \mathrm{~mm}$ ) inserted through an overtube (TS-13140; outer diameter $13.2 \mathrm{~mm}$ ); or a colonoscope EC 450BI5 (working channel $2.8 \mathrm{~mm}$; outer

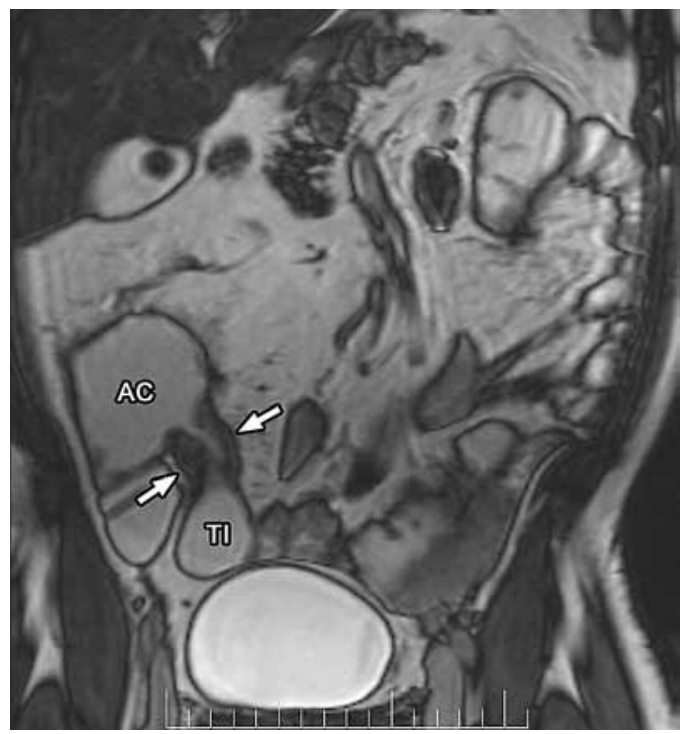

Fig. 4: $\mathrm{MR}$ enteroclysis $-\mathrm{T} 2$ weighted image in coronal plane. Circumferential thickening of the ileo-colonic anastomosis (AC - ascending colon, TI - terminal ileum) and $30 \mathrm{~mm}$ of the neoterminal ileum (arrows) 


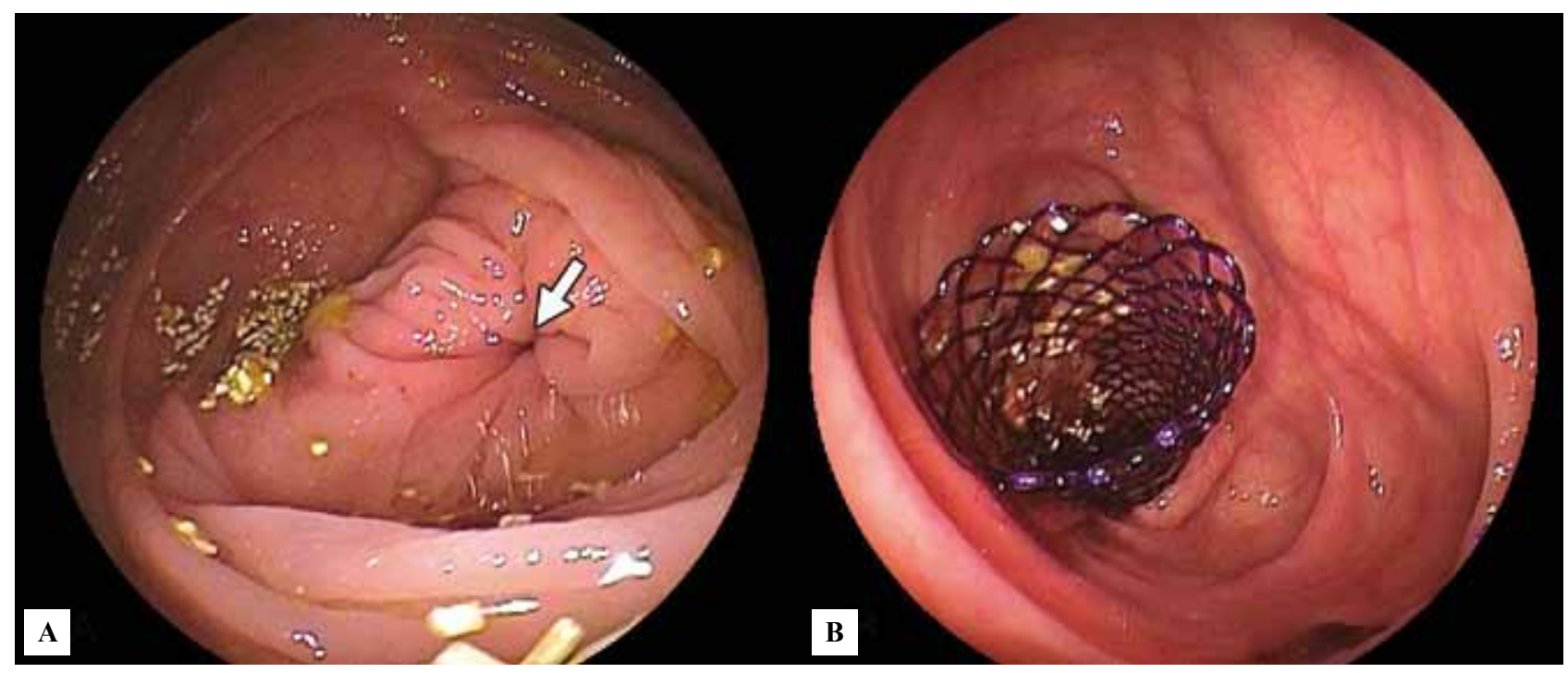

Fig. 5: Endoscopic view of the ileo-colonic anastomosis (arrow) (A - left). Bio-degradable stent deployed across the anastomosis (B - right)

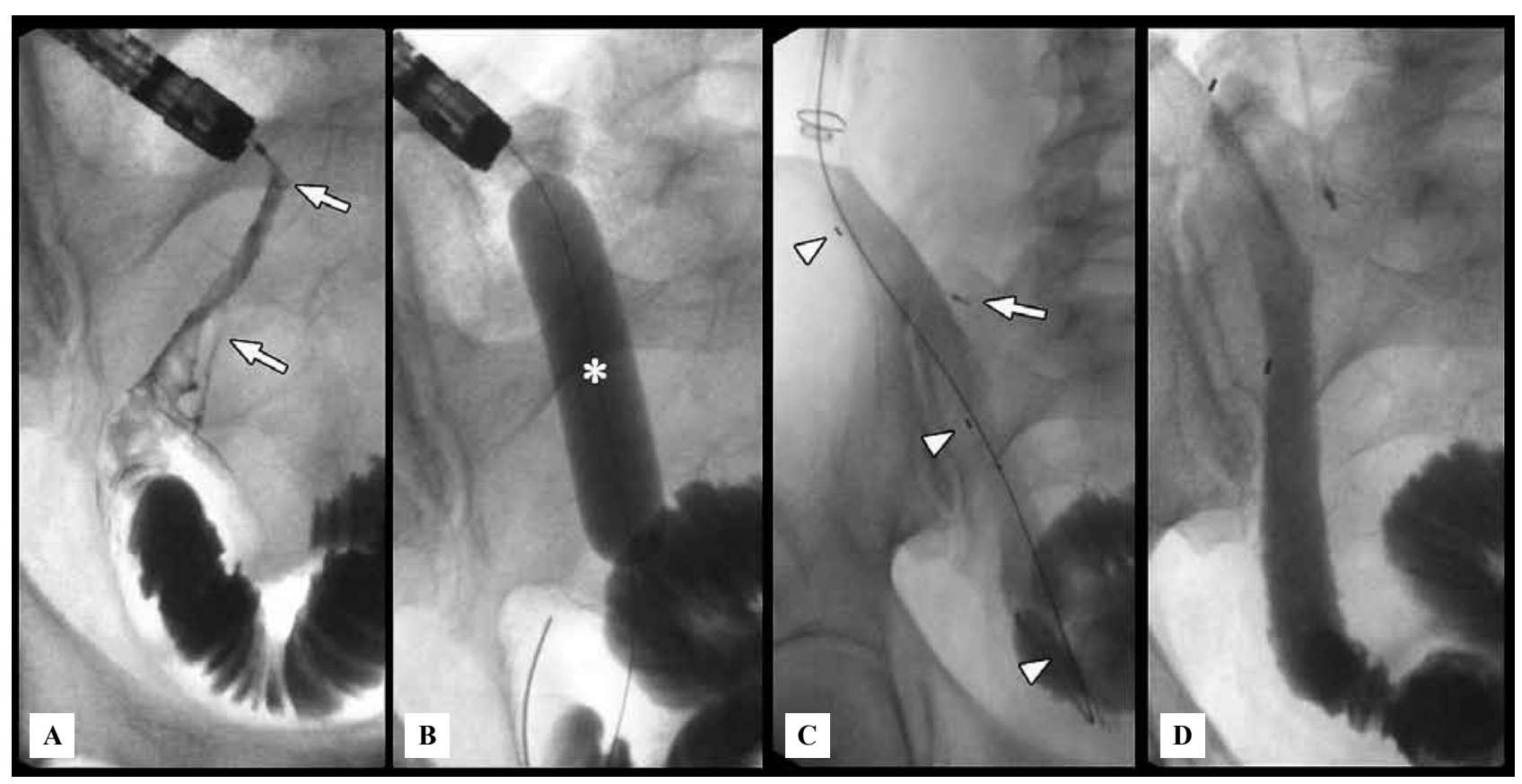

Fig. 6: Fluoroscopy images before and after stent insertion (the same patient as in Figure 5). A: stenosis (arrows) of the ileocolonic anastomosis. B: balloon (asterisk) dilation. C: bio-degradable stent with three radio-opaque markers (arrowheads) immediately after deployment from the introducer. The proximal margin of the stenosis has been marked by an endoscopic clip (arrow). D: Deployed bio-degradable stent with free passage of contrast medium

diameter $9.4 \mathrm{~mm}$ ) inserted through an overtube (TS-13101; outer diameter $13.2 \mathrm{~mm}$ ). For details, see Ref. 48.

Intestinal stenoses were dilated first by through-thescope balloon dilation (Rigiflex, Boston Scientific, Natick, USA), distal margins of stenoses were marked with metallic clips and/or lipiodol injection. The inflated balloon on the tip of the overtube secured the correct stable position during the procedure. Biodegradable stents were implanted over a stiff guide wire by means of a special introducer inserted into the enteroscope overtube after the removal of the endoscope. Stent placement was accomplished under fluoroscopy control. Twisting or curling of the balloon overtube (mainly at 
the splenic flexure) during the introducer insertion was the only technical problem. The enteroscope or colonoscope, used without a distal balloon to allow their smooth pull-out through an overtube, was immediately reinserted via this overtube to check correct stent position. See Figures 5 and 6 for details.

\section{Results}

We have published our initial results in detail elsewhere (48). Briefly, insertion of bio-degradable stents was successful at the first attempt in all but one case. We failed to introduce a bio-degradable stent into a stenosis of the descending colon in a 35-year-old man because of fixed sharp bending at the sigmoideo-descending junction. No complications occurred in the remaining cases of successful insertion. Early, short-lived, mild and dull abdominal pain did not require painkillers. Bio-degradable stent insertion provided rapid clinical improvement and symptom relief in all but one patient. Subsequent follow-up was 2 to 19 months (mean 10, median 10 months). We recorded early stent migration in three patients (within one day to two months). In another case (a 33-year-old woman with stenosis of the ileo-sigmoideal anastomosis), the proximal flared end of the stent started to abut the intestinal wall (without stent migration) two months after implantation, resulting in intermittent obstruction (see Figure 7). The proximal end of the stent was trimmed endoscopically by means of hot biopsy

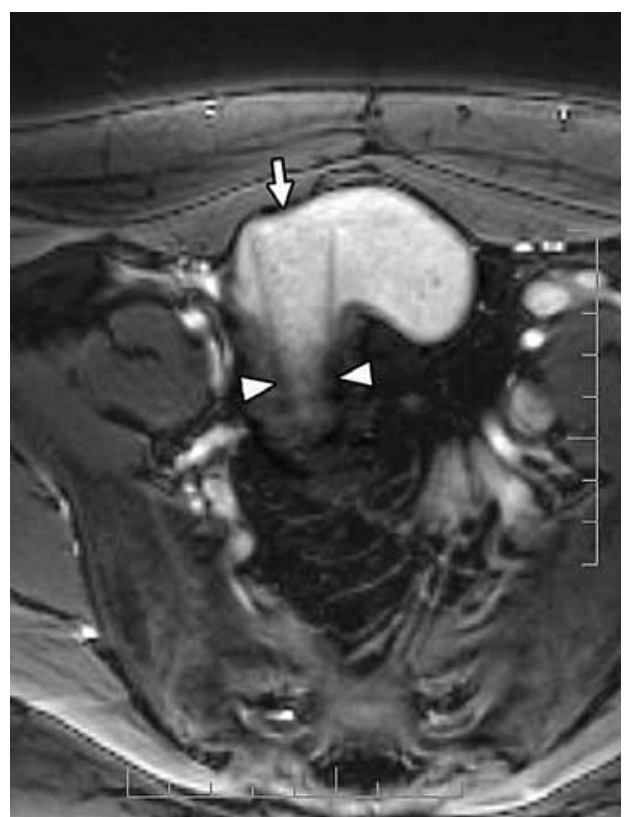

Fig. 7: Magnetic resonance scan - T2 weighted image in axial plane. The end of the biodegradable stent (arrow) protruding from the stenosis of ileo-sigmoideal anastomosis (arrowheads) is abutting the ileal wall, causing intermittent obstruction ("chimney effect") forceps (see Figure 8) and the stent migrated spontaneously five days later (see Figure 9). A good clinical result with symptom-relief beyond stent expulsion was also achieved in this patient. The mean time until stent degradation in the remaining patients was 4 months. Information concerning the long-term efficacy and safety of the procedure is not yet available.

\section{Efficacy of bio-degradable stents for benign small intestinal stenoses and remaining problems to be solved}

Tight intestinal Crohn's stenoses and strictures complicating other diseases cause significant morbidity. Previously, these were treated by surgical resections (often extensive) or stricturoplasty. They can now be dilated endoscopically $(10,49,50)$, although the clinical effect of this treatment

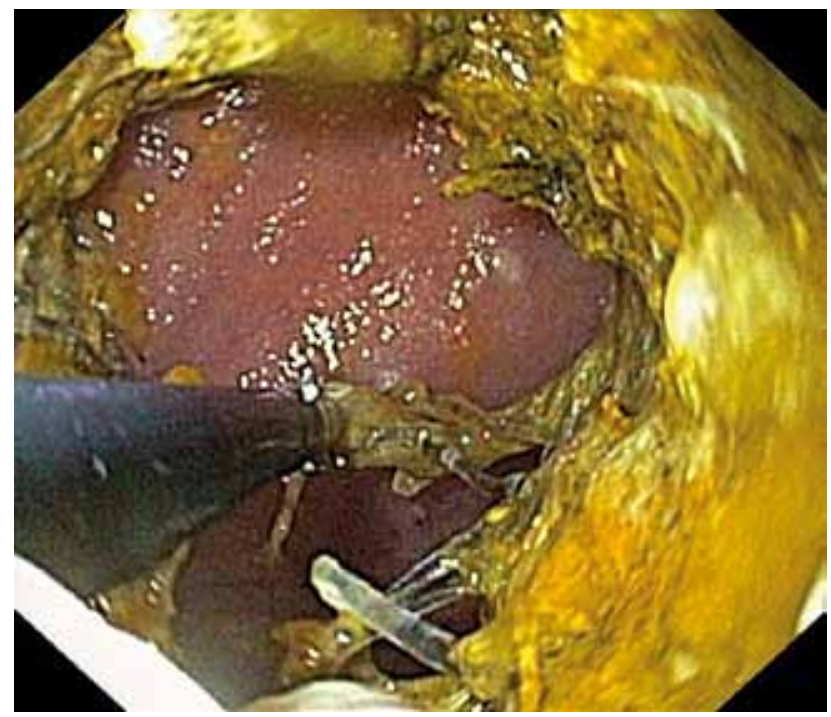

Fig. 8: Bio-degradable stent being shredded by means of hot biopsy forceps

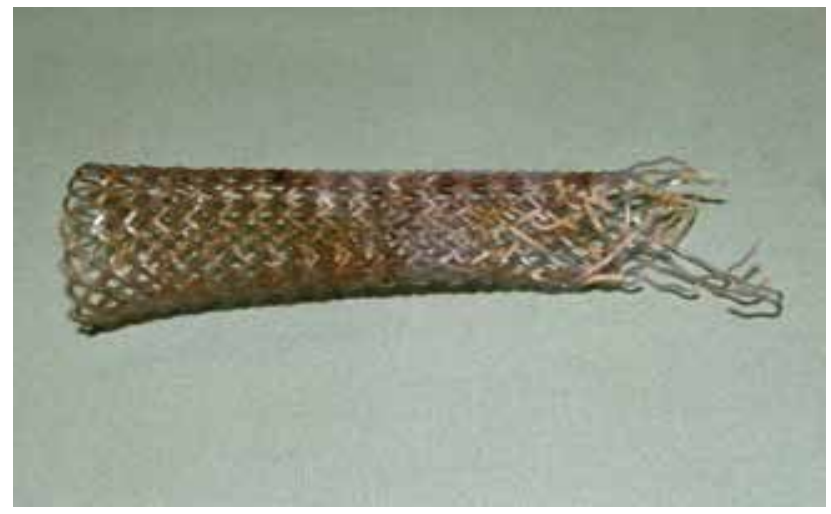

Fig. 9: Spontaneously migrated bio-degradable stent from the ileo-sigmoideal anastomosis after trimming 
is often limited or short-lived and repeated dilations with perforation risk and repeated endoscopies are frequently necessary. Bio-degradable stents may present a new therapeutical option. These stents can be made of different synthetic polymers (like polylactide or polyglycolide) or their co-polymers (polydioxanone). Their degradation is a hydrolytic one, first the amorphous and then the crystalline structure is broken down. The speed of biodegradation is dependent not only on the size and structure (crystallinity, porosity, hydrophilic backbone etc.) but also influenced by temperature, $\mathrm{pH}$ and type of body tissue/fluid $(51,52)$. To date, bio-degradable stents have mostly been tried for benign refractory oesophageal strictures $(16,24,36,38,40-43)$. Some of these reports have so far been published only as abstracts.

Existing experience with the use of bio-degradable stents for small and large intestinal stenoses is still in its early stages. Only a limited number of patients were included and long-term efficacy and safety results cannot yet be evaluated. Intestinal implantation of a bio-degradable stent is technically possible and relatively simple. However, there are still some difficulties that need to be overcome. The rate of early migration of the stent was rather high in our initial group (3/10 patients). This might be solved by changes in shape or stent structure. Further improvement in the design of bio-degradable stents will be required.

An ideal stent for benign stenoses would be one that has a large diameter, high expansion ratio, axial flexibility, optimal delivery system, withstands ingrowth, maintains lumen integrity, does not cause stent-induced mucosal or parenchymal injury, and does not need a repeat endoscopy for removal. Bio-degradable stents seem to be the correct way of achieving this goal in the future.

\section{Conclusions}

Endoscopic introduction of bio-degradable stents into benign small and large intestinal stenoses is feasible and relatively simple. Proof of the long-term efficacy and safety requires further studies, but improvements in stent design are required to overcome the problem of migration.

\section{Acknowledgements}

This work was supported by research project MZO 00179906 from the Ministry of Health, Czech Republic.

\section{References}

1. McLoughlin MT, Byrne MF (2008) Endoscopic stenting - where we are now and where can we go? World J Gastroenterol 14: 3798-3803.

2. Matsushita M, Hajiro K, Takakuwa H, Nishio A, Kusumi F (2000) Plastic prosthesis in the palliation of small bowel stenosis secondary to recurrent gastric cancer: initial cost saving. Gastrointest Endoscopy 52: 571-573.

3. Maetani I, Ukita T, Inone H, Yoshida M, Igarashi Y, Sakai Y (2001). Knitted nitinol stent insertion for various intestinal stenoses with a modified delivery system. Gastrointest Endoscopy 54: 364-367.

4. Kawase A, Kakemura T, Maetani I, Igarashi Y, Sakai Y (2001) Placement of additional stent for recanalizing procedure of occluded jejunal stent. Gastrointes Endoscopy 54: 394-397.
5. Yim HB, Jacobson BC, Saltzman JR, Johannes RS, Bounds BC, Lee JH, Shields SJ, Ruymann FW, Van Dam J, Carr-Locke DL (2001) Clinical outcome of the use of enteral stents for palliation of patients with malignant upper GI obstruction. Gastrointest Endoscopy 53: 329-332.

6. Baron TH, Harewood GC (2003) Enteral self-expandable stents. Gastrointest Endoscopy 58: 421-433.

7. Ross AS, Semrad C, Waxman I, Dye C (2006) Enteral stent placement by double balloon enteroscopy for palliation of malignant small bowel obstruction. Gastrointest Endoscopy 64: 835-837.

8. Lennon AM, Chandrasekhara V, Shin EJ, Okolo PI (2010) Spiral-enteroscopy-assisted enteral stent placement for palliation of malignant small-bowel obstruction. Gastrointest Endoscopy 71: 422-425.

9. Wayman J, Bliss R, Richardson DL, Griffin SM (1998) Self-expanding metal stents in the palliation of small bowel stenosis secondary to recurrent gastric cancer. Gastrointest Endoscopy 47: 286-290.

10. Rejchrt S, Kopacova M, Tacheci I, Bures J (2008) Interventional double balloon endoscopy for Crohn's, gastrointestinal bleeding, and foreign body extraction. Tech Gastrointest Endoscopy 10: 101-106.

11. Tierney W, Chuttani R, Croffie J, DiSario J, Liu J, Mishkin DS, Shah R, Somogyi L, Petersen BT (2006) Enteral stents. Gastrointest Endosc 63: 920-926.

12. Kita H, Yamamoto H (2006) Double-balloon endoscopy for the diagnosis and treatment of small intestinal disease. Best Pract Res Clin Gastroenterol 20: 179-194.

13. Yamamoto H, Kita H, Sunada K, Hayashi Y, Sato H, Yano T, Iwamoto M, Sekine Y, Miyata T, Kuno A, Ajibe H, Ido K, Sugano K (2004) Clinical outcomes of doubleballoon endoscopy for the diagnosis and treatment of small-intestinal disease. Clin Gastroenterol Hepatol 2: 1010-1016.

14. Bickston SJ, Foley E, Lawrence C, Rockoff T, Shaffer HA, Yeaton P (2005) Terminal ileal stricture in Crohn's disease: treatment using a metallic enteral endoprosthesis. Dis Colon Rectum 48: 1081-1085.

15. Mönkemüller K, Bellutti M, Fry LC, Malfertheiner P (2008) Enteroscopy. Best Pract Res Clin Gastroenterol 22: 789-811.

16. Bhasin DK, Rana SS (2008) Biodegradable pancreatic stents: are they a disappearing wonder? Gastrointest Endosc 67: 1113-1115.

17. Freeman ML (2001) Bioabsorbable stents for gastrointestinal endoscopy. Tech Gastrointest Endoscopy 3: 120-125.

18. Judah JR, Draganov PV (2007) Endoscopic therapy of benign biliary strictures. World J Gastroenterol 13: 3531-3539.

19. Bleier BS, Paulson DP, O'Malley BW, Li D, Palmer JN, Chiu AG, Cohen NA (2009) Chitosan glycerophosphate-based semirigid dexamethasone eluting biodegradable stent. Am J Rhinol Allergy 23: 76-79.

20. Costa JR, Abizaid A, Costa R, Feres F, Tanajura LF, Abizaid A, Mattos LA, Staico R, Siqueira D, Sousa AG, Bonan R, Sousa JE (2008) Preliminary results of the hydroxyapatite nonpolymer-based sirolimus-eluting stent for the treatment of single de novo coronary lesions a first-in-human analysis of a third-generation drug-eluting stent system. JACC Cardiovasc Interv 1: 545-551.

21. Guo O, Knight PT, Mather PT (2009) Tailored drug release from biodegradable stent coatings based on hybrid polyurethanes. J Control Release 137: 224-233.

22. Hermawan H, Dubé D, Mantovani D (2010) Degradable metallic biomaterials: design and development of Fe-Mn alloys for stents. J Biomed Mater Res A 93: $1-11$.

23. Macaya C, Moreno R (2008) Bioabsorbable drug-eluting stents: the future of coronary angioplasty? Nat Clin Pract Cardiovasc Med 5: 598-599.

24. Saito Y, Tanaka T, Andoh A, Minematsu H, Hata K, Tsujikawa T, Nitta N, Murata K, Fujiyama Y (2007) Usefulness of biodegradable stents constructed of poly1-lactic acid monofilaments in patients with benign esophageal stenosis. World J Gastroenterol 13: 3977-3980.

25. Wykrzykowska JJ, Onuma Y, Serruys PW (2009) Advances in stent drug delivery: the future in bioabsorbable stents. Expert Opin Drug Deliv 6:113-126.

26. Han Y, Jing Q, Xu B, Yang L, Liu H, Shang X, Jiang T, Li Z, Zhang H, Li H, Qiu J, Liu Y, Li Y, Chen X, Gao R and CREATE (Multi-center registry of excel biodegradable polymer drug-eluting stents) investigators (2009) Safety and efficacy of biodegradable polymer-coated sirolimus-eluting stents in "real-world" practice: 18-month clinical and 9-month angiographic outcomes. JACC Cardiovasc Interv 2: 303-309.

27. Onuma Y, Serruys P, den Heijer P, Joesoef KS, Duckers H, Regar E, Kukreja N, Tanimoto S, Garcia-Garcia HM, van Beusekom H, van der Giessen W, Nishide T (2009) MAHOROBA, first-in-man study: 6-month results of a biodegradable polymer sustained release tacrolimus-eluting stent in de novo coronary stenoses. Eur Heart J 30: 1477-1485.

28. Windecker S, Serruys PW, Wandel S, Buszman P, Trznadel S, Linke A, Lenk K, Ischinger T, Klauss V, Eberli F, Corti R, Wijns W, Morice MC, di Mario C, Davies S, van Geuns RJ, Eerdmans P, van Es GA, Meier B, Jümi P (2008) Biolimus-eluting stent with biodegradable polymer versus sirolimus-eluting stent with durable polymer for coronary revascularisation (LEADERS): a randomised non-inferiority trial. Lancet 372: 1163-1173.

29. Ramcharitar S, Serruys PW (2008) Fully biodegradable coronary stents: progress to date. Am J Cardiovasc Drugs 8: 305-314. 
30. Ginsberg G, Cope C, Shah J, Martin T, Carty A, Habecker P, Kaufmann C, Clerc C, Nuutinen J-P, Törmälä P (2003) In vivo evaluation of a new bioabsorbable selfexpanding biliary stent. Gastrointest Endoscopy 58: 777-784.

31. Meng B, Wang J, Zhu N, Meng QY, Cui FZ, Xu YX (2006) Study of biodegradable and self-expandable PLLA helical biliary stent in vivo and in vitro. J Mater Sci Mater Med 17: 611-617.

32. Laukkarinen J, Nordback I, Mikkonen J, Kärkkäinen P, Sand J (2007) A novel biodegradable biliary stent in the endoscopic treatment of cystic-duct leakage after cholecystectomy. Gastrointest Endosc 65: 1063-1068.

33. Laukkarinen J, Lämsä T, Nordback I, Mikkonen J, Sand J (2008) A novel biodegradable pancreatic stent for human pancreatic applications: a preclinical safety study in a large animal model. Gastrointest Endosc 67: 1106-1112.

34. Lämsä T, Jin H, Mikkonen J, Laukkarinen J, Sand J, Nordback I (2006) Biocompatibility of a new bioabsorbable radiopaque stent material $\left(\mathrm{BaSO}_{4}\right.$ containing poly-L,D-lactide) in the rat pancreas. Pancreatology 6: 301-305.

35. Parviainen M, Sand J, Harmoinen A, Kainulainen H, Välimaa T, Törmälä P, Nordback I (2000) A new biodegradable stent for the pancreaticojejunal anastomosis after pancreaticoduodenal resection: in vitro examination and pilot experiences in humans. Pancreas 21: 14-21

36. Fry SW, Fleischer DE (1997) Management of a refractory benign esophageal stricture with a new biodegradable stent. Gastrointest Endosc 45: 179-182.

37. Goldin E, Fiorini A, Ratan Y, Keter D, Loshakove A, Globerman O, Beyar M (1996) A new biodegradable and self-expandable stent for benign esophageal strictures. Gastrointest Endosc 43: 294.

38. Tanaka T, Takahashi M, Nitta N, Furukawa A, Andoh A, Saito Y, Fujiyama Y, Murata K (2006) Newly developed biodegradable stents for benign gastrointestinal tract stenoses: a preliminary clinical trial. Digestion 74: 199-205.

39. Saito Y, Tanaka T, Andoh A, Minematsu H, Hata K, Tsujikawa T, Nitta N, Murata K, Fujiyama Y (2008) Novel biodegradable stents for benign esophageal strictures following endoscopic submucosal dissection. Dig Dis Sci 53: 330-333.

40. Bychkova OV, Lazyuk II, Averin V (2009) Bio-degradable stents - new approach to the treatment of caustic stenoses in children. Folia Gastroenterol Hepatol 7 : 30-34. Available from http://www.pro-folia.org.

41. Dhar A, Topping JH, Johns E, O’Neill D (2009) Biodegradable stents in refractory benign oesophageal strictures - first report of 4 patients from UK. Gastrointest Endoscopy 69: AB254-AB255.

42. Stivaros SM, Williams LR, Senger C, Wilbraham L, Laasch HU (2010) Woven polydioxanone biodegradable stents: a new treatment option for benign and malignant oesophageal strictures. Eur Radiol 20: 1069-1072.

43. Repici A, Vleggaar F, Carlino A, Van Boeckel PG, Romeo F, Siersema PD (2009) Benign refractory esophageal strictures: preliminary results from the BEST (Biodegradable Esophageal STent) study. Gastrointest Endoscopy 69: AB123.

44. Petrtyl J, Bruha R, Horak L, Zadorova Z, Dosedel J, Laasch HU (2010) Management of benign intrahepatic bile duct strictures: initial experience with polydioxanone biodegradable stents. Endoscopy 42 Suppl 2: E89-90.

45. Janik V, Horak L, Hnanicek J, Malek J, Laasch HU (2011) Biodegradable polydioxanone stents: a new option for therapy-resistant anastomotic strictures of the colon. Eur Radiol. 21: 1956-61.

46. Rejchrt S, Kopacova M, Bartova J, Bures J (2009) Intestinal biodegradable stents. Initial experience in the Czech Republic. Folia Gastroenterol Hepatol 7: 7-11. Available from http://www.pro-folia.org.

47. England R (2008) Implant of SX-ELLA BD biodegradable stent in patient with post radiotherapy benign oesophageal stricture. BD Clinical Bulletin A44pp. UK Medical Limited: Sheffield, 2008. Available from: http://www.ukmedical.com.

48. Rejchrt S, Kopacova M, Brozik J, Bures J (2011) Biodegradable stents for the treatment of benign stenoses of the small and large intestines. Endoscopy 43: 911-917.

49. Kopacova M, Bures J, Vykouril L, Hladik P, Simkovic D, Jon B, Ferko A, Tacheci I, Rejchrt S (2007) Intraoperative enteroscopy. Ten years' experience at a single tertiary center. Surg Endoscopy 21: 1111-1116.

50. Kopacova M, Rejchrt S, Tacheci I, Bures J (2007) Hyperamylasemia of uncertain significance associated with oral double-balloon enteroscopy. Gastrointest Endoscopy 66: $1133-1138$.

51. Freudenberg S, Rewerk S, Kaess M, Weiss C, Dorn-Beinecke A, Post S (2004) Biodegradation of absorbable sutures in body fluids and $\mathrm{pH}$ buffers. Eur Surg Res 36: $376-385$

52. Gunatillake P, Mayadunne R, Adhikari R (2006) Recent developments in biodegradable synthetic polymers. Biotechnol Annu Rev 12: 301-347.

Received: $23 / 08 / 2011$

Accepted in revised form: 17/10/2011

\section{Corresponding author:}

Stanislav Rejchrt, Professor, MD, PhD, 2nd Department of Medicine, Charles University Teaching Hospital, Sokolská 581, 50005 Hradec Králové, Czech Republic; e-mail: rejchrt@lfhk.cuni.cz 